\title{
Peningkatan Aktivitas dan Hasil Belajar PKn Materi Globalisasi Melalui Model Pembelajaran Talking Stick dengan Media Visual
}

\section{Tri Utami Asri*}

\section{A R T I C L E I N F O}

Article history:

Received 12 December 2019

Received in revised form

01 January 2020

Accepted 30 January 2020

Available online 27

February 2020

\section{Kata Kunci:}

Aktivitas dan Hasil

Belajar, Model Talking

Stick, Media Visual

Keywords:

Activity and Learning

Outcomes, Talking Stick

Model, Visual Media

\begin{abstract}
A B S T R A K
Tujuan penelitian ini adalah untuk meningkatkan aktivitas dan hasil belajar PKn materi Globalisasi melalui model pembelajaran Talking Stick dengan Media Visual pada siswa kelas IV SD 2 Kaliwungu Semester II Tahun Pelajaran 2017/2018. Penelitian ini menggunakan desain penelitian tindakan kelas yang dilakukan dalam dua siklus dengan masing-masing siklus terdiri dari dua pertemuan. Teknik pengumpulan data yang digunakan yaitu teknik tes dan non tes. Teknik non tes berupa pengamatan terhadap aktivitas siswa. Hasil penelitian menunjukkan adanya peningkatan aktivitas dan hasil belajar siswa. Aktivitas siswa pada siklus I mendapat skor 20,63 atau sebesar 72,63\% (cukup), meningkat menjadi 24,9 atau sebesar $88,5 \%$ (sangat baik) pada siklus II. Hasil belajar pada pratindakan diperoleh nilai rata-rata 66,50 ketuntasan klasikal $45 \%$, sedangkan pada siklus I nilai rata-rata mencapai 76,25 dengan ketuntasan klasikal $70 \%$. Pada siklus II nilai rata-rata mencapai 81,75 dengan ketuntasan klasikal $90 \%$, mengalami peningkatan sebesar $20 \%$ dari siklus I dan 35\% dari pratindakan. Berdasarkan hasil yang diperoleh, disimpulkan bahwa penerapan model Talking Stick dengan Media Visual terbukti dapat meningkatkan aktivitas dan hasil belajar PKn materi Globalisasi pada siswa kelas IV SD 2 Kaliwungu Semester II Tahun Pelajaran 2017/2018.
\end{abstract}

A B S T R A C T

The purpose of this study was to improve the activities and learning outcomes of the Civics Civics material through the Talking Stick learning model with Visual Media in fourth grade students of Kaliwungu Elementary School 2 Semester II in the Academic Year 2017/2018. This study uses a classroom action research design conducted in two cycles with each cycle consisting of two meetings. Data collection techniques used are test and non-test techniques. Non-test technique in the form of observation of student activity. The results showed an increase in student activity and learning outcomes. Student activities in the first cycle scored 20.63 or $72.63 \%$ (enough), increasing to 24.9 or $88.5 \%$ (very good) in the second cycle. Learning outcomes in the pre-action obtained an average value of 66.50 classical completeness of $45 \%$, while in the first cycle the average value reached 76.25 with a classical completeness of $70 \%$. In cycle II the average value reached 81.75 with $90 \%$ classical completeness, an increase of $20 \%$ from the first cycle and 35\% from the pre-action. Based on the results obtained, it was concluded that the application of the Talking Stick model with Visual Media was proven to be able to increase the activities and learning outcomes of Civics Civics material in class IV SD 2 Kaliwungu 2nd Semester II Academic Year 2017/2018. 


\section{Pendahuluan}

Belajar adalah proses mereaksi terhadap semua situasi yang ada di sekitar individu. Belajar adalah proses yang diarahkan kepada tujuan, proses berbuat melalui berbagai pegalaman. Belajar adalah proses melihat, mengamati, dan memahami sesuatu (Sudjana, 2011:28). Belajar adalah suatu proses usaha yang dilakukan seseorang untuk memperoleh suatu perubahan tingkah laku yang baru secara keseluruhan, sebagai hasil pengalamannya sendiri dalam interaksi dengan lingkungannya (Daryanto, 2013:2). Aktivitas merupakan prinsip penting dalam interaksi belajar mengajar. Menurut Hamalik (2011:14) aktivitas belajar adalah hubungan timbal balik antara guru dengan siswa dalam pembelajaran sehingga siswa dituntut agar memiliki semangat dan dorongan untuk belajar. Menurut Sardiman, (2011: 99) belajar perlu adanya aktivitas karena merupakan rangkaian kegiatan meliputi keaktifan siswa dalam mengikuti pembelajaran, bertanya, mencatat, mendengar, berfikir, membaca dan segala kegiatan yang dapat menunjang prestasi belajar.

Hasil belajar adalah perubahan-perubahan yang terjadi pada diri siswa, baik yang menyangkut aspek kognitif, afektif, dan psikomotor sebagai hasil dari kegiatan belajar (Susanto, 2013:5). Menurut Sudjana (2011:22), "hasil belajar adalah kemampuan-kemampuan yang dimiliki siswa setelah ia menerima pengalaman belajarnya". Hasil belajar pada dasarnya merupakan hasil akhir dalam proses pembelajaran yang digunakan sebagai ukuran keberhasilan pembelajaran. Menurut Susanto (2013:42) hasil belajar adalah aktivitas peserta didik yang mencerminkan materi yang telah diserap dalam proses belajar, cerminan tersebut berupa sikap (afektif), nalar berpikir (kognitif), dan keteguhan hidup (psikomotorik). Jadi, dapat disimpulkan bahwa hasil belajar merupakan perubahan kemampuan berpikir, bersikap, dan berketerampilan yang diperoleh siswa setelah menerima pengetahuan.

Menurut Pour (2018) Pendidikan merupakan salah satu aspek penting bagi kehidupan manusia. Pendidikan yang berkualitas sangat diperlukan untuk mendukung terciptanya manusia yang cerdas serta mampu bersaing di era globalisasi. Pendidikan mempunyai peranan yang sangat besar dalam membentuk karakter, perkembangan ilmu dan mental seorang anak, yang nantinya akan tumbuh menjadi seorang manusia dewasa yang akan berinteraksi dan melakukan banyak hal terhadap lingkungannya, baik secara individu maupun sebagai makhluk sosial. Pembelajaran Pendidikan Kewarganegaraan tidak hanya berpatokan pada penilaian aspek kognitif saja, akan tetapi pada aspek afektif dan psikomotorik. Dalam kegiatan belajar mengajar, guru lebih banyak mengejar target yang berorientasi pada nilai ujian akhir. Hal ini berkaitan pada pembentukan karakter, moral, sikap serta perilaku siswa yang hanya menginginkan nilai yang baik tanpa diimbangi dengan perbaikan karakter, moral, sikap serta perilaku dari anak tersebut.

Permasalahan tersebut juga terjadi pada pembelajaran PKn di kelas IV SD 2 Kaliwungu Kudus. Hasil refleksi kondisi awal di kelas IV yaitu kualitas pembelajaran PKn masih rendah, akibatnya siswa cenderung kurang antusias, merasa bosan, dan pasif dalam mengikuti proses kegiatan pembelajaran. Sebagian besar siswa belum sepenuhnya bertanggungjawab untuk memperhatikan materi pelajaran yang sedang diajarkan, sebagian siswa justru asik berbicara dengan teman sebangkunya dan mengganggu teman lainnya. Akibatnya, siswa kurang memahami materi pelajaran yang diajarkan, sehingga hasil belajar PKn siswa kelas IV SD 2 Kaliwungu Kudus kurang maksimal.

Permasalahan diatas didukung dengan adanya data hasil evaluasi pembelajaran PKn siswa kelas IV SD 2 Kaliwungu Kudus belum mencapai nilai di atas Kriteria Ketuntasan Minimal (KKM) 75. Dari 20 siswa kelas IV, hanya 9 siswa (45\%) yang mendapat nilai di atas KKM 75, sedangkan sisanya 11 siswa (55\%) masih di bawah KKM 75, akibatnya aktivitas dan hasil belajar PKn menjadi kurang maksimal, sehingga perlu adanya perbaikan kualitas pembelajaran.

Salah satu solusi yang dapat dilakukan berdasarkan permasalahan di atas, yaitu menerapkan model Talking Stick dalam pembelajaran PKn. Talking Stick merupakan model pembelajaran yang menekankan kerjasama antara siswa dan guru untuk mencapai tujuan bersama. Model pembelajaran ini juga efektif karena memungkinkan siswa dapat belajar secara optimal, yang pada gilirannya akan dapat meningkatkan hasil belajar siswa. Menurut Lidia (2018) dari model-model pembelajaran kooperatif, tipe Talking stick paling sesuai karena dalam pembelajaran ini siswa dituntut untuk bisa saling bekerja sama bersama dengan kelompok, serta mampu menjawab pertanyaan-pertanyaan mengenai materi yang sedang dipelajari sehingga dapat meningkatkan hasil belajar.Menurut Huda (2017) Metode Talking Stick adalah proses pembelajaran dengan bantuan tongkat yang berfungsi sebagai alat untuk menentukan siswa yang akan menjawab pertanyaan. Pembelajaran dengan metode Talking Stick bertujuan untuk mendorong siswa agar berani mengemukakan pendapat. Metode pembelajaran Talking Stick dalam proses belajar mengajar di kelas berorientasi pada terciptanya kondisi belajar melalui permainan tongkat yang diberikan dari satu siswa kepada siswa yang lainnya. Tongkat digulirkan dengan diiringi musik. Pada saat musik berhenti maka siswa yang sedang memegang tongkat itulah yang memperoleh kesempatan untuk menjawab pertanyaan tersebut. Menurut Safitri (2018) Model Talking Stick merupakan salah satu 
model yang yang menekankan pada keterlibatan peserta didik pada proses belajar mengajar, untuk berani mengemukakan pendapat. Model ini dapat memberikan motivasi kepada peserta didik supaya belajar aktif dalam memahami dan menemukan konsep, sehingga peserta didik mampu menghubungkan soal dengan teori yang ada. Pada proses pembelajaran dengan menggunakan model talking stick guru harus mampu berperan sebagai motivator dan fasilitator agar proses pembelajaran dapat berlangsung dengan efektif, untuk itu guru harus memiliki wawasan pengetahuan yang luas dan mampu memanfaatkan teknologi modern, dan potensi lingkungan sekitar untuk dijadikan sebagai sumber belajar dan media pembelajaran. Menurut Suprijono, (2012:109) Talking Stick merupakan model pembelajaran kelompok dengan bantuan tongkat. Langkah-langkah dalam penerapan Talking Stick adalah: 1) Penjelasan guru tentang materi pokok yang akan dipelajari; 2) Siswa membaca dan mempelajari materi; 3) Guru meminta siswa menutup buku catatan kemudian mengambil tongkat dan memberikan pada salah satu siswa; 4) Siswa yang menerima tongkat diwajibkan menjawab pertanyaan dari guru; 5) Refleksi; dan 6) Merumuskan kesimpulan. Menurut Huda, (2013:225) model Talking Stick bermanfaat karena mampu menguji kesiapan siswa untuk fokus berkonsentrasi dalam situasi apapun, melatih keterampilan dalam membaca dan memahami materi pelajaran dengan cepat dan tepat sehingga siswa tidak pasif dalam pembelajaran. Kemudian dalam Suprijono, (2012:109) menyatakan pembelajaran dengan model Talking Stick mendorong siswa untuk berani mengajukan pendapat. Penggunaan model ini diharapkan dapat mendorong keaktifan siswa untuk berpendapat dan meningkatkan minat belajar siswa sehingga kualitas pembelajaran PKn dapat meningkat. Model Talking Stick lebih efektif jika didukung dengan penggunaan media pembelajaran yang sesuai, yaitu media visual untuk menunjang pembelajaran PKn agar penyajian materi kepada siswa lebih optimal. Dalam penelitian Amir (2016) menyatakan bahwa model pembelajaran kooperatif tipe talking stick dapat membuat siswa tidak merasa jenuh, menyenangkan siswa dan meningkatkan kreativitas belajar siswa, sehingga alternatif yang diambil peneliti untuk mengatasi masalah diatas yaitu dengan menerapkan model pembelajaran kooperatif tipe talking stick. Menurut Daryanto (2013:17), media visual merupakan semua alat peraga yang digunakan dalam proses belajar yang bisa dinikmati lewat panca indera mata. Media visual memegang peran yang penting dalam proses belajar. Menurut, Djamarah (2010:124), media visual adalah media yang hanya mengandalkan indra penglihatan. Selain itu, menurut Sudjana (2011:8), pengajaran sebagai upaya terencana dalam membina pengetahuan sikap dan keterampilan para siswa melalui interaksi siswa dengan lingkungan belajar yang diatur guru pada hakikatnya mempelajari lambang-lambang verbal dan visual. Oleh karena itu, pengajaran dikatakan dikatakan efektif apabila penerima pesan (siswa) dapat memahami makna yang dipesankan oleh guru sebagai lingkungan belajarnya. Penerapan model Talking Stick lebih efektif apabila didukung dengan media visual. Penggunaan model pembelajaran Talking Stick dengan media visual dapat membuat siswa aktif dan produktif dalam pembelajaran serta mendorong siswa untuk belajar berfikir kritis dengan memecahkan permasalahan-permasalahan yang terkandung dalam media yang disajikan, sehingga kualitas pembelajaran PKn kelas IV SD 2 Kaliwungu dapat meningkat.

Adapun tujuan penelitian ini adalah untuk meningkatkan aktivitas siswa melalui model pembelajaran Talking Stick dengan media visual dalam pembelajaran PKn materi Globalisasi pada kelas IV SD 2 Kaliwungu semester II Tahun Pelajaran 2017/2018.

\section{Metode}

Penelitian tindakan kelas dilakukan di kelas IV SD 2 Kaliwungu semester II tahun pelajaran 2017/2018 dengan subjek penelitian 20 siswa.

Penelitian dilaksanakan dalam dua siklus. Setiap siklus terdiri empat tahap kegiatan, yaitu perencanaan (planing), pelaksanaan tindakan (acting), pengamatan (observing) dan refleksi (reflecting).

Pada tahap perencanaan ini, kegiatan yang dilakukan adalah membuat skenario pembelajaran dengan menyusun RPP yang terdapat proses pembelajaran model Talking Stick dengan media visual. Pelaksanaan tindakan (acting) dilaksanakan sesuai skenario pembelajaran yang direncanakan. Pada tiaptiap siklus yaitu menerapkan pembelajaran model talking stick dengan media visual. Siklus II merupakan hasil pengembangan atas refleksi hasil siklus I.

Pengamatan (observing) pada kegiatan ini peneliti dibantu oleh satu orang observer untuk melaksanakan observasi terhadap pelaksanaan tindakan untuk mengetahui sejauh mana penguasaan siswa dalam pembelajaran. Observasi dilaksanakan bersamaan pelaksanaan tindakan dengan menggunakan lembar observasi yang telah dibuat. Aspek-aspek yang diamati adalah keaktifan siswa selama proses pembelajaran berlangsung serta hasil tes pada akhir siklus. Hasil analisis data yang dilaksanakan dalam tahap ini digunakan sebagai acuan untuk melaksanakan siklus berikutnya. 
Refleksi (reflecting) hasil observasi yang meliputi aktifitas siswa selama proses belajar mengajar, hasil tes pada akhir siklus juga kendala-kendala yang dihadapi selama kegiatan pembelajaran dikumpulkan serta dikaji sehingga diperoleh hasil refleksi kegiatan untuk mengetahui perubahan yang terjadi selama menerapkan pembelajaran ini. Hasil analisis data yang dilaksanakan dalam tahap ini digunakan sebagai acuan untuk melaksanakan siklus berikutnya.

Teknik pengumpulan data dengan mendeskripsikan hasil tes dilakukan secara langsung kepada siswa untuk memperoleh data tentang hasil belajar siswa pada proses pembelajaran secara benar dan tepat. Metode tes digunakan untuk memperoleh data tentang tingkat kemampuan penguasaan materi pembelajaran sebelum dan sesudah pembelajaran.

Teknik analisis melalui dua tahap, yaitu 1) menggunakan teknik analisis deskriptif yaitu hasil tes kondisi awal, siklus I dan siklus II, sehingga setelah dianalisis hasil siklus I dan siklus II ada peningkatan; dan 2) menggunakan teknik observasi dengan analisis diskriptif berdasarkan hasil observasi dan refleksi untuk mengetahui kemajuan hasil yang dicapai dalam pembelajaran.

Data yang sudah terkumpul kemudian dianalisis untuk mengukur indikator keberhasilan yang telah dirumuskan yaitu: 1) untuk mengukur keaktifan siswa menggunakan kriteria secara klasikal mencapai kategori baik atau lebih dari 75\%; 2) hasil belajar PKn dianggap meningkat apabila dapat mencapai ketuntasan belajar individual sebesar ( $\geq 75$ ) dan ketuntasan klasikal mencapai 80\%.

\section{Hasil dan Pembahasan}

Kondisi awal atau sebelum diadakan tindakan penelitian ini rata-rata klasikal hasil belajar PKn kelas IV SD 2 Kaliwungu Kudus adalah 66,50, di bawah standar Kriteria Ketuntasan Minimal (KKM) yaitu sebesar 65\% atau nilai 65 secara individual dan 80\% secara klasikal. Untuk mengatasi kondisi tersebut maka dilakukan suatu tindakan kelas untuk meningkatkan hasil belajar siswa dalam pembelajaran PKn melalui model Jigsaw dengan media visual.

Data hasil pelaksanaan tindakan pada siklus I diperoleh melalui tes formatif I, dan observasi selama proses pembelajaran. Tes formatif I dilaksanakan untuk mengetahui hasil belajar siswa, sedangkan observasi dilakukan untuk mengetahui aktivitas belajar siswa.

Hasil observasi aktivitas siswa pada pelaksanaan tindakan siklus I dengan menerapkan model Talking Stick dengan media visual pada pembelajaran PKn kelas IV SD 2 Kaliwungu Kudus diperoleh data sebagai berikut:

Berdasarkan hasil observasi aktivitas siswa pada pembelajaran PKn melalui model pembelajaran Talking Stick dengan media visual pada siklus I mengalami peningkatan. Siswa terlihat antusias pada saat mengikuti kegiatan pembelajaran, siswa memperhatikan penjelasan guru. Namun masih ada beberapa siswa yang masih malu untuk bertanya atau mengeluarkan pendapatnya. Aktivitas siswa dalam diskusi cukup baik, tetapi sebagian kecil yang berani maju untuk mempresentasikan hasil kelompoknya. Aktivitas belajar siswa pada siklus I sebesar 72,63\% dengan persentase aktivitas pertemuan I sebesar 70,50\% serta persentase aktivitas pertemuan II sebesar 74,75\%. Dari data tersebut dapat disimpulkan bahwa hasil observasi aktivitas belajar siswa belum berhasil untuk mencapai indikator yang ditentukan pada aktivitas belajar siswa yaitu sebesar $\geq 75 \%$ meskipun pada aktivitas belajar siswa pada kategori sedang atau cukup baik.

Hasil belajar siklus I dengan menerapkan model pembelajaran Talking Stick dengan media visual, diperoleh data sebagai berikut: dari 20 siswa, ada 14 siswa atau 70\% yang mengalami ketuntasan belajar, dan yang 6 siswa atau 30\% belum tuntas dalam belajar. Ada peningkatan sebesar 25\% atau 5 siswa yang sudah tuntas. Selain itu nilai tertinggi yang dicapai siswa pada siklus I adalah 100 dan nilai terendah 50, sedangkan nilai rata-rata yang dicapai adalah 76,75. Dengan demikian ketuntasan belajar pada siklus I cukup baik, namun masih perlu diperbaiki lagi supaya hasilnya sesuai dengan indikator keberhasilan yang diharapkan.

Berikut rekapitulasi hasil belajar siswa pada siklus I yang disajikan dalam bentuk Tabel.

Tabel 1. Hasil Belajar Siswa Siklus I

\begin{tabular}{lcccc}
\hline \multicolumn{1}{c}{ Rentang Nilai } & Kategori & Frek & Nilai & Persen \\
\hline $94-100$ & SB & 3 & 300 & $15 \%$ \\
$85-93$ & Baik & 4 & 350 & $20 \%$ \\
$75-84$ & Cukup & 7 & 535 & $35 \%$ \\
$\leq 75$ & Kurang & 6 & 340 & $30 \%$ \\
\hline Jumlah & & $\mathbf{2 0}$ & $\mathbf{1 5 2 5}$ & $\mathbf{1 0 0 \%}$ \\
\hline
\end{tabular}




\begin{tabular}{lcccc}
\hline Rata-Rata & & & $\mathbf{7 6 , 7 5}$ & \\
\hline Tuntas & $\geq 75$ & 14 & $\mathbf{7 0 \%}$ \\
\hline Belum tuntas & $\leq 75$ & 6 & $30 \%$ \\
\hline
\end{tabular}

Berdasarkan Tabel 1 diketahui penerapan model pembelajaran talking stick dengan media visual diperoleh data bahwa ada 14 siswa atau sebesar 70\% mengalami ketuntasan belajar secara klasikal, sedangkan siswa yang mendapatkan nilai di bawah KKM secara klasikal ada 6 siswa atau sebesar 30\%.

Hasil belajar siswa pada siklus I diperoleh ketuntasan klasikal hasil belajar siswa sebesar $70 \%$ (14 dari 20 siswa). Hasil tersebut belum memenuhi indikator keberhasilan yang ditetapkan yaitu sebesar $80 \%$, sehingga perlu dilakukan tindakan pembelajaran pada siklus berikutnya.

Kegiatan pembelajaran siklus II berlangsung sangat efektif, siswa antusias melakukan diskusi karena terjadi interaksi harmonis dalam satu kelompok maupun antar kelompok. Siswa saling menanggapi hasil temuan kelompok lain dan berpendapat secara logis melalui model pembelajaran Talking Stick dengan media visual.

Aktivitas belajar siswa pada tindakan siklus II mengalami banyak peningkatan dibandingkan saat siklus I. Aktivitas belajar siswa pada siklus II sebesar $90,73 \%$ dengan persentase aktivitas pertemuan I sebesar $87,92 \%$ serta persentase aktivitas pertemuan II sebesar 93,54\%. Berdasarkan data hasil pengamatan aktivitas siswa dalam pembelajaran PKn melalui model Talking Stick dengan media visual pada siklus II, diperoleh skor 21,78 dan rata-rata skor aktivitas siswa sebesar 3,63. Persentase keberhasilan sebesar 90,73\% dengan kategori sangat baik. Dari data tersebut dapat disimpulkan bahwa hasil observasi aktivitas belajar siswa sudah berhasil mencapai indikator yang ditentukan pada aktivitas belajar siswa yaitu sebesar $\geq 75 \%$.

Pada tindakan pembelajaran siklus II menunjukkan peningkatan pada hasil belajar siswa. Ketuntasan belajar klasikal yang dicapai sebesar 90\% artinya masih ada 2 siswa (10\%) belum tuntas/mencapai nilai KKM. Hal ini dapat dilihat pada Tabel 2 berikut.

Tabel 2. Hasil Belajar Siswa Siklus II

\begin{tabular}{lcccc}
\hline \multicolumn{1}{c}{ Rentang Nilai } & Kategori & Frek & Nilai & Persen \\
\hline $94-100$ & SB & 4 & 400 & $20 \%$ \\
$85-93$ & Baik & 6 & 515 & $30 \%$ \\
$75-84$ & Cukup & 8 & 600 & $40 \%$ \\
$\leq 75$ & Kurang & 2 & 120 & $10 \%$ \\
\hline Jumlah & & $\mathbf{2 0}$ & $\mathbf{1 6 3 5}$ & $\mathbf{1 0 0 \%}$ \\
\hline Rata-Rata & & & $\mathbf{8 1 , 7 5}$ & \\
\hline Tuntas & $\geq \mathbf{7 5}$ & $\mathbf{1 8}$ & & $\mathbf{9 0 \%}$ \\
\hline Belum tuntas & $\mathbf{5 7 5}$ & $\mathbf{2}$ & & $\mathbf{1 0 \%}$ \\
\hline
\end{tabular}

Hasil tes formatif siklus II mengalami peningkatan. Pencapaian nilai rata-rata kelas pada siklus I mencapai 76,25 dan pada siklus II meningkat menjadi 81,75. Pada pelaksanaan siklus II terdapat jumlah siswa yang tuntas belajar yaitu 18 siswa dengan persentase ketuntasan belajar 90\%, sedangkan 2 siswa tidak tuntas belajar dengan persentase $10 \%$. Hal ini menunjukkan ada peningkatan dari siklus I ke siklus II mencapai $20 \%$. Hasil ini termasuk memuaskan karena sudah memenuhi indikator, yang telah ditetapkan yaitu ketuntasan klasikal belajar siswa minimal 80\%.

Pada pembelajaran sebelum tindakan penelitian, peneliti hanya mengandalkan metode konvensional yaitu ceramah, tanya jawab, dan pemberian tugas, sehingga hasil yang dicapai adalah siswa yang memperoleh nilai 75 ke atas hanya 9 dari 20 siswa atau 45\%. Dengan nilai terendah 40, nilai tertinggi 90 dan nilai rata-rata 66,50. Berdasarkan hasil tersebut peneliti bermaksud untuk meningkatkan aktivitas dan hasil belajar siswa dengan melaksanakan model pembelajaran Talking Stick dengan media visual.

Hasil belajar siswa pada siklus I, nilai rata-rata kelas yang diperoleh mencapai 76,25 ini berarti rata-rata kelas pada siklus I sudah mencapai indikator keberhasilan yang diharapkan yaitu sekurangkurangnya rata-rata kelas mencapai nilai 75 . Sementara untuk persentase siswa yang tuntas belajar pada siklus I juga sudah mencapai 70\%. Artinya 70\% dari 20 siswa yaitu sebanyak 14 siswa memperoleh nilai tes formatif lebih dari atau sama dengan 75 . Dengan kata lain 14 siswa sudah tuntas belajar. Sedangkan persentase untuk siswa yang tidak tuntas belajar adalah 30\%. Hal ini berarti 30\% dari 20 siswa yaitu sebanyak 6 siswa memperoleh nilai tes formatif kurang dari 75 .

Hasil belajar siswa pada siklus I dapat dikatakan belum mencapai indikator keberhasilan. Ketuntasan belajar yang dicapai adalah $80 \%$. Ini merupakan batas minimal ketuntasan belajar yang harus 
dicapai. Dari 20 siswa berarti sebanyak 14 siswa mendapat nilai sama dengan atau lebih dari nilai KKM yaitu 75. Rata-rata kelas yang dicapai juga sudah memenuhi indikator keberhasilan yaitu sekurangkurangnya mendapat nilai 75 sedangkan rata-rata kelasnya adalah 75 . Kedua aspek tersebut belum mencapai indikator keberhasilan. Meskipun indikator keberhasilan sudah dicapai untuk hasil belajar tetapi masih perlu adanya perbaikan agar pencapaian hasil belajar pada siklus selanjutnya lebih baik. Kekurangan yang terjadi pada siklus I akan dijadikan acuan perbaikan pada pertemuan selanjutnya.

Hasil pengamatan aktivitas siswa secara keseluruhan diperoleh pada siklus I adalah 74,08\%. Pada siklus I pertemuan 1 persentase aktivitas belajar siswa sebesar 71,25\%, pada pertemuan 2 sebesar 76,94\%. Rata-rata persentase secara keseluruhan pada siklus I sebesar 74,08\%. Aktivitas ini tergolong pada kriteria cukup baik namun belum mencapai indicator keberhasilan yang ditetapkan. Secara indikator yang memperoleh persentase rendah pada siklus I yaitu keaktifan siswa pada saat penyajian materi menggunakan model talking stick. Hal ini dikarenakan model ini merupakan hal baru bagi siswa sehingga siswa justru sibuk membicarakan model yang disajikan dan tidak memperhatikan pelajaran, selain itu penggunaan media ini masih kurang maksimal.

Agar aktivitas belajar lebih baik sehingga hasil belajarpun lebih baik maka pada siklus II dilakukan perbaikan dalam proses pembelajaran. Peneliti memaksimalkan model talking stick dengan media visual. Dalam diskusi kelompok, guru memberikan pujian bagi kelompok yang rajin sehingga memotivasi kelompok lain agar rajin pula. Penguatan juga diberikan bagi siswa yang aktif bertanya atau maju mempresentasikan hasil belajar tanpa ditunjuk guru.

Pada pembelajaran siklus II, penerapan model pembelajaran talking stick berbasis media visual pada materi globalisasi mengalami peningkatan yang cukup baik. Hal tersebut dapat diketahui dari hasil belajar siswa pada siklus II, nilai rata-rata kelas yang diperoleh adalah 81,75. Nilai rata-rata kelas sudah lebih dari 75 (KKM), ini berarti rata-rata kelas pada siklus II sudah mencapai indikator keberhasilan yang diharapkan yaitu sekurang-kurangnya rata-rata kelas mencapai nilai 75 (KKM). Sementara untuk persentase siswa yang tuntas belajar pada siklus II adalah 90\%. Artinya 90\% dari 20 siswa yaitu sebanyak 18 siswa memperoleh nilai tes formatif lebih dari atau sama dengan 75. Dengan kata lain 18 siswa sudah tuntas belajar. Adapun persentase untuk siswa yang tidak tuntas belajar adalah $10 \%$. Hal ini berarti $10 \%$ dari 20 siswa yaitu hanya 2 siswa memperoleh nilai tes formatif kurang dari 75.

Peningkatan hasil belajar ini menunjukkan bahwa siswa mengalami perubahan tingkah laku selama mengikuti model pembelajaran Talking Stick dengan media visual perolehan hasil belajar pada siklus I dijadikan pengalaman bagi siswa agar pada siklus II memperoleh hasil yang lebih baik.

Aktivitas belajar siswa pada siklus II mengalami peningkatan di setiap indikator yang diamati. Pada siklus I perolehan aktivitas belajar siswa sebesar 74,08\% dan meningkat pada siklus II menjadi $90,73 \%$. Dari kriteria cukup baik menjadi sangat baik. Keaktifan ini sudah melebihi indikator keberhasilan $(\geq 75 \%)$.

Penerapan model talking stick dengan media visual sudah maksimal dimana pada saat guru memberikan pertanyaan disertai dengan menyanyi agar stick dapat berjalan ke seluruh kelas, mereka sudah siap menjawab pertanyaan tersebut. Selain itu sesekali peneliti juga mengajukan pertanyaan yang berkaitan dengan materi. Sebagian besar siswa aktif mencatat dan bertanya jawab pada saat penyajian materi pelajaran. Kemudian di siklus II siswa sudah tebiasa dengan kegiatan berkelompok sehingga siswa mau bekerja sama di dalam kelompoknya dan tidak lagi malu untuk mengemukakan pendapatnya.

Data hasil tindakan penelitian pada aktivitas belajar siswa persentase ketuntasan secara klasikal, yaitu $74,08 \%$ pada siklus I dan 90,73\% pada siklus II. Meningkatnya persentase aktivitas belajar siswa pada siklus II ditunjukkan dengan meningkatnya keterlibatan siswa selama proses pembelajaran. Siswa sudah memiliki keberanian dalam berpendapat atau menanggapi pernyataan teman. Selain itu, rasa percaya diri siswa dalam mempresentasikan hasil diskusi semakin tinggi, hal ini dibuktikan dengan suara lantang dan sikap tegas siswa dalam melakukan presentasi. Perubahan-perubahan perilaku siswa pada siklus I dan II telah membuktikan bahwa, penerapan model Talking Stick dengan media visual pada pembelajaran PKn materi globalisasi di SD 2 Kaliwungu Kudus dapat meningkatkan aktivitas belajar siswa.

\section{Simpulan dan Saran}

Berdasarkan hasil penelitian yang telah dilakukan dapat disimpulkan sebagai berikut: Dengan menerapkan model Talking Stick berbasis media visual, dapat meningkatkan aktivitas dan hasil belajar PKn materi globalisasi pada siswa kelas IV SD 2 Kaliwungu Semester II Tahun Pelajaran 2017/2018.

Penerapan model Talking Stick dengan media visual memberikan pengalaman belajar yang baru bagi siswa kelas IV SD 2 Kaliwungu Kudus. Siswa memiliki kesempatan yang luas untuk memecahkan masalah dalam dunia nyata melalui pengetahuan awal siswa. Kegiatan pembelajaran model talking stick 
dengan media visual dapat mendorong siswa untuk meningkatkan kemampuan berpikir siswa dalam menyelesaikan masalah yang sering ia dapati dalam kehidupan sehari-hari.

Berdasarkan hasil penelitian pada pembelajaran PKn materi globalisasi melalui model talking stick dengan media visual pada siswa kelas IV SD 2 Kaliwungu Kudus, maka dapat disarankan sebagai berikut: 1) Bagi guru agar dapat mencoba untuk menerapkan model talking stick dalam proses pembelajaran di kelas dan merancang kegiatan pembelajaran sesuai dengan langkah-langkah talking stick sebagai salah satu solusi untuk meningkatkan kualitas pembelajaran PKn meliputi aktivitas siswa dan hasil belajar siswa; 2) Bagi siswa agar lebih termotivasi untuk belajar dengan adanya inovasi pembelajaran yang diterapkan guru dalam pembelajaran di kelas, sehingga dengan berjalannya waktu akan muncul kesadaran siswa untuk belajar sebagai suatu kebutuhan; 3) Bagi pihak sekolah perlu menyediakan sarana dan mengambil kebijakan-kebijakan yang mendukung pelaksanaan model pembelajaran talking stick pada berbagai pelajaran. Model pembelajaran Talking Stick dengan media visual perlu disosialisasikan agar lebih sering diterapkan dalam pembelajaran di sekolah untuk meningkatkan performansi guru, aktivitas belajar siswa dan hasil belajar siswa.

\section{Daftar Rujukan}

Amir, A. (2016). Pembelajaran Matematika dengan Menggunakan Model Kooperatif Tipe Talk ing Stick. Jurnal [Online]. Logaritma Vol IV, No. 01, 16 halaman. Tersedia: http://ejournal. perpustakaanstainpsp.net/index.php/logaritma/article/view/369.

Djamarah, Saiful Bahri. 2010. Strategi Belajar Mengajar. Jakarta: PT Rineka Cipta.

Daryanto. 2013. Media Pembelajaran. Bandung: Satu Nusa

Hamalik, Oemar. 2011. Kurikulum dan Pembelajaran. Jakarta: Bumi Aksara

Huda, Miftahul. 2013. Cooperative Learning Metode Teknik Struktur dan Model Penerapan. Yogyakarta: Pustaka Belajar.

Huda, Fathul. 2017. Penerapan Model Pembelajaran Talking Stick untuk Meningkatkan Hasil Belajar Pokok Bahasan Pancasila sebagai Dasar Negara Republik Indonesia Kelas Vi Tahun Pelajaran 2017/2018, Jurnal PTK dan Pendidikan Vol. 3 No. 2. Juli Hal.45-54. Tersedia Pada: https://jurnal.uin-antasari.ac.id/index.php/ptkpend/article/download/1958/1495.

Lidia, Wijayanti, Nanis Hairunisya, Imam Sukwatus Sujai. 2018. Pengaruh Model Talking Stick terhadap Hasil Belajar IPS. Jurnal Teori dan Praksis Pembelajaran IPS Volume 3, No.2, Hal. 81-87. Tersedia Pada: http://iournal2.um.ac.id/index.php/itppips/article/download/4682/pdf.

Pour, Agustina Novitasari, Lovy Herayanti, Baiq Azmi Sukroyanti. 2018. Pengaruh Model Pembelajaran Talking Stick terhadap Keaktifan Belajar Siswa. Jurnal Penelitian dan Pengkajian Ilmu Pendidikan: e-Saintika Vol. 2 No. 1 December 2018, pp. 36-40. Tersedia Pada: https://ejournal.litpam.org/index.php/e-Saintika/article/view/111.

Safitri, Ikra, Misykat Malik Ibrahim, Nursalam. 2018. Pengaruh Penerapan Model Talking Stick dengan Bantuan Media Choose Number terhadap Hasil Belajar Biologi di SMP Negeri 3 Sungguminasa Kabupaten Gowa. Jurnal Biotek Volume 6 Nomor 1 Hal. 131-144. Tersedia Pada: http://journal.uin-alauddin.ac.id/index.php/biotek/article/view/5144/0.

Sardiman. 2011. Interaksi \& Motivasi Belajar Mengajar. Jakarta: Rajawali Pers

Sudjana, Nana. 2011. Penilaian Hasil Proses Belajar Mengajar. Bandung: PT Remaja Rosdakarya

Suprijono, Agus. 2012. Cooperative Learning Teori dan Aplikasi PAIKEM. Yogyakarta: Pustaka Pelajar

Susanto, Ahmad. 2013. Teori Belajar dan Pembelajaran di Sekolah Dasar. Jakarta: Prenada Media Grup 